\title{
O PROCESSO FORMULÁRIO
}

\author{
THE FORMULARY PROCEDURE
}

Handel Martins Dias*

\begin{abstract}
Resumo:
Este trabalho realiza uma análise perfunctória, por meio de pesquisa em fontes de cognição técnicas e não-técnicas, mormente na doutrina romanística pátria e italiana, do processo formulário, que sobreveio como uma alternativa mais moderna em relação às legis actiones. Embora permanecesse cabendo ao iudex o julgamento da causa, ampliaram-se significativamente os poderes do pretor durante o período formulário. Além disso, por meio de seus editos, os pretores passaram a corrigir iniquidades e a suprir lacunas do antigo direito quiritário. Essa autêntica atividade normativa desempenhada pelos pretores foi fundamental para o desenvolvimento do Direito, material e processual, permanecendo até hoje o seu legado.

Palavras-chave: Processo. Romano. Processo formulário. Pretor. Edito. Equidade.
\end{abstract}

\begin{abstract}
:
This paper presents a brief analysis, based on a research conducted using both technical and non-technical cognition sources, principally the opinion of Brazilian and Italian Romanistic jurists, about the formulary procedure, which has come as a most modern alternative in relation to the legis actiones procedure. Notwithstanding the iudex remaining the one in charge of deciding the case, the powers of the praetor have increased expressively during the formulary period. Furthermore, by means of their edicts, the praetors have started to correct inequities and fill in the gaps of the old quiritary right. This authentic rulemaking activity performed by the praetors was essential for the development of both substantive and procedural Law, leaving a legacy that still lasts today.
\end{abstract}

Keywords: Procedure. Roman. Formulary procedure. Praetor. Edict. Equity.

\section{Introdução}

Ainda hoje, quiçá para sempre, ecoam fortemente na humanidade efeitos da antiga civilização romana. No âmbito do Direito, essa influência aufere contornos próprios e consistentes. Resultado de treze séculos de evolução do Direito Romano desde a fundação de Roma (VIII a.C.), a codificação de Justiniano delineia a base do direito dos povos do Ocidente, especialmente naqueles países que integram a família romanogermânica, como é o caso do Brasil por força do legado lusitano. O sistema romano-

\footnotetext{
Mestre em Direito pela Universidade Federal do Rio Grande do Sul. Doutor em Direito pela Faculdade de Direito da Universidade de São Paulo. Advogado e Professor de Direito Processual Civil do Centro Universitário Metodista-RS.
} 
germânico é proveniente do Direito comum da Idade Média, formado fundamentalmente pelo Direito Romano, pelo Direito Canônico e por institutos de natureza consuetudinária de origem bárbaro-germânica. As Ordenações do Reino, que influenciaram decisivamente o direito brasileiro, têm como fonte direta o ius comune medievo, com diversas reproduções literais de disposições romanas. Como se não bastasse, o Direito Romano era aplicado de forma subsidiária, tal como o canônico, em caso de lacuna nas Ordenações. Já as Afonsinas, de 1446, previam que "quando o caso, de que se trauta, nom for determinado por Ley do Regno, mandamos que seja julgado, e findo pelas Leyx Imperaaes, e pelos Santos Canones" (Livro II, tít. VIII). ${ }^{1}$

A ascendência desse patrimônio jurídico de séculos ocorreu de forma assaz no Direito Pátrio, máxime no âmbito do Direito Privado e do Processo Civil. Sublinha José Carlos Moreira Alves que o Ordenamento Jurídico Civil brasileiro encontra-se paradoxalmente mais romanizado do que o próprio Direito lusitano contemporâneo. Isso porque, a partir do século XIX, sobretudo após a independência do Brasil, Portugal sofreu forte influência da legislação civil francesa e afastou-se dos princípios romanos, diferentemente do que ocorreu no Brasil, onde persistiu a ascendência romana (2005). Fenômeno semelhante ocorreu no tocante ao Direito Processual. Toda a construção lógica do processo pátrio permanece até os dias de hoje sendo senão aquela desenvolvida em Roma. Enrico Tullio Liebman esposava que a presença do processo comum medieval desenvolvido na Europa continental também está bem mais acentuada no Brasil do que na própria Europa (1951, passim).$^{2}$

Diante de toda essa influência, mostra-se imprescindível o estudo do Direito Romano para se compreender mais profunda e adequadamente o Direito brasileiro. ${ }^{3}$ Como ensina José Manuel Pérez-Prendes Muñoz-Arraco, o estudo retrospectivo constitui a única via possível para a compreensão da essência do Direito (1996, p.13). ${ }^{4}$ Dentre tantos

Sobre a aplicação subsidiária do Direito Romano e do Direito Canônico nas Ordenações do Reino, veja-se o clássico CRUZ, Guilherme Braga da. O direito subsidiário na história do direito português. Coimbra: Universidade de Coimbra, 1975.

2 Naturalmente, que o Processo Civil brasileiro também herdou uma forte influência do Direito Canônico. Vejam-se, a respeito, TUCCI, José Rogério Cruz e; AZEVEDO, Luiz Carlos de. Lições de processo civil canônico: história e direito vigente. São Paulo: Revista dos Tribunais, 2001; e DIAS, Handel Martins. A influência do processo canônico no processo civil brasileiro. Intertemas: Revista da Toledo, Presidente Prudente, v. 16, 2011. (no prelo).

3 Para o estudo dessa temática, recomenda-se TUCCI, José Rogério Cruz e; AZEVEDO, Luiz Carlos de. Lições de história do processo civil romano. São Paulo: Revista dos Tribunais, 2001. Esta obra, referencial teórico para o presente ensaio, abarca o conteúdo programático do primeiro semestre da cadeira de "História do processo romano, canônico e lusitano" no Curso de Pós-Graduação da Faculdade de Direito da Universidade de São Paulo.

4 A respeito da relevância do estudo histórico do direito, veja-se AZEVEDO, Luiz Carlos de. História do direito, ciência e disciplina. Revista da Faculdade de Direito, Universidade de São Paulo. São Paulo, v. 92, p. 31-49, 1997. E especificamente sobre a importância do estudo do Direito Romano, veja-se ALVES, José 
pontos de interesse do Direito Romano, merece destaque o processo formulário, em que houve, por meio do pretor, significativa evolução do direito e ampliação da participação do "Estado" na solução dos litígios. ${ }^{5} \mathrm{O}$ objetivo do presente ensaio é examinar o processo formulário, introduzido de forma oficial pela lex Aebutia entre 149 e 126 a.C. e vigorante, já de forma esporádica, até o governo de Diocleciano (285-305 d.C.). Para isso, realizase, de início, a título propedêutico, um breve estudo do Processo romano durante a período das ações da lei, compreendido desde a fundação de Roma (754 a.C.) até o fim da República (27 a.C.). ${ }^{6}$ Concluído o exame do primeiro sistema Processual Romano, que consubstancia, junto com o processo formulário, o ordo iudiciorum privatorum, encetase, de fato, o estudo do processo formulário, mas especificamente de suas origens. À continuação, analisa-se o procedimento formular, fases in iure e apud iudicem, bem como a actio iudicati. Por fim, abarca-se a notável atividade criadora do pretor desempenhada neste período, instituindo novos direitos com base em seu poder discricionário e inspirado na equidade.

\section{O sistema processual antecedente}

O processo é um fato social, na medida em que nele se reflete a cultura, a ideologia e o estado da civilização em que consubstancia. ${ }^{7}$ Esta máxima aufere especial realce no contexto do processo civil romano, que se conformou sobremaneira com os valores e as mentalidades reinantes em cada época. Nos primórdios de Roma, em que a defesa privada ainda tinha larga utilização e a segurança dos romanos dependia mais do grupo a que pertenciam do que do "Estado", a religião e o misticismo eram elementos

Carlos Moreira. Universidade, cultura e direito romano. Revista Trimestral de Jurisprudência dos Estados, São Paulo, Jurid Vellenich, 1994. v. 121, p. 9-28.

5 A cidade de Roma era o próprio Estado, como ressalta Geraldo de Ulhoa Cintra (1963, p. 11). Todavia, não se constituía propriamente em um Estado na compreensão contemporânea. É comumente classificado como Estado antigo, o mais remoto antecedente do que se convencionou chamar de Estado moderno. Veja-se JELLINEK, Geog. Teoría general del estado. Buenos Aires: Albatros, 1954. p. 215, p. 234-237.

6 A demarcação do Processo Romano pela doutrina moderna em três grandes períodos - legis actiones, per formulas e extraordinaria cognitio - é apenas convencional, pois houve coexistência de sistemas processuais durante a transição de um sistema para outro, além da existência de fases ou mesmo ulteriores sistemas particulares dentro de cada um dos períodos. Por conta disso, ainda que presentes três períodos bem nítidos, resta realmente impreciso quando e em que medida cada qual deixou de viger, cedendo passo ao subsequente (TUCCI; AZEVEDO, 2001a, p. 39-40).

7 O processo é um fato cultural, na medida em que nele se reflete toda uma cultura, considerada como o conjunto de vivência de ordem espiritual e material que singularizam determinada época de uma sociedade. Por isso, nada mais natural que sua função varie conforme a época e a mentalidade reinante (LACERDA, 1961, p. 74-75). Este fato também foi consignado por Mauro Cappelletti em seu conhecido ensaio Ideologie nel diritto processuale. In: CAPPELLETTI, Mauro. Processo e ideologie. Bologna: Il Molino, 1969. p. $3-54$. 
marcantes. $^{8}$ Naturalmente, toda essa religiosidade e primitividade influenciaram fortemente o pioneiro sistema Processual Romano - das ações da lei (legis actiones) que perdurou durante toda a época régia (fundação de Roma até a expulsão dos reis em 510 a.C.) e republicana (510-27 a.C.). Eram inclusive os pontífices quem ditavam, com o auxílio do Rei, o comportamento dos cidadãos e o solene ritual, eivado de simbolismo, que deveria ser observado pelas partes. ${ }^{9}$

Neste primeiro período do Processo romano, classificado modernamente como ações da lei, havia cinco diferentes ações: a sacramentum, ${ }^{10}$ a iudicis postulatio, ${ }^{11}$ a condictio, ${ }^{12}$ a manus iniectio ${ }^{13}$ e a pignoris capio, ${ }^{14}$ sendo a primeira a mais importante porque era o rito residual, aplicado para reivindicar direitos de natureza pessoal e real quando incabíveis os demais (Gaio, I., 4.12-13). As legis actiones eram assim denominadas por estarem as ações, ou as situações jurídicas que se pretendia por meio delas tutelar, expressamente previstas em leis (Gaio, I., 4.11), ${ }^{15}$ primeiro na Lei das XII

8 Veja-se PUGLIESE, Giovanni. Il processo civile romano. Roma: Ricerche, 1961-2. v. 1: Le legis actiones, p. 27 e ss.

9 TUCCI; AZEVEDO, 2001a, p. 41. Segundo os dois autores, esse íntimo relacionamento entre direito (ius) e religião (fas) foi motivo determinante não apenas para que a estrutura jurídica das legis actiones fosse por demais formalista, mas também para a incerteza entre os romanistas quanto à delimitação dos poderes do rei (Id. Ibid.).

10 Era a mais antiga ação da lei, a par da manus iniectio, e a primeira forma institucionalizada de processo. Por meio dela, permitia-se tanto o exercício de direitos de natureza pessoal (actio sacramento in personam) como o exercício de direitos de natureza real (actio sacramento in rem). Sobre a legis actio per sacramentum, veja-se CINTRA, Geraldo de Ulhoa. De actione sacramento. São Paulo: [s.n.], 1960.

11 A legis actio per iudicis arbtrive postulationem foi uma ação pessoal instituída pela Lei das XII Tábuas. Era cabível especificamente para a cobrança de dívidas originadas de promessa de pagamento, bem como para a partilha de herança e, a partir da pela Lei Licínia, para a divisão de coisa comum (Gaio, I., 4.17a.).

12 A legis actio per condictionem foi uma ação pessoal instituída pelas leis Sília e Calpúrnia, respectivamente para cobrar quantia certa devida ou crédito de decorrente de coisa certa (certa re). Gaio referenciou que era objeto de polêmica a criação desta ação porque as suas duas hipóteses de cabimento permitiam a actio sacramentum ou ainda, conforme o caso, a iudicis postulatio (Gaio, I., 4.20). Ao encontro do defendido por Lévy-Bruhl, esposam Tucci e Azevedo que provavelmente a legis actio per condictionem foi instituída em substituição à legis actio sacramento in personam, por ser formalmente menos complicada e mais evoluída do que aquela (2001a, p. 67-68).

13 A legis actio per manus iniectionem foi uma típica ação de execução, pois era cabível basicamente quando não havia o adimplemento da obrigação originada de sentença (iudicatus) ou confissão (confessus). Depois, foram editadas leis, como é o caso das Leis Fúria e Márcia, prevendo a manus iniectio para outras situações, não decorrentes da coisa julgada. A propósito, veja-se Gaio, I., 4.21-23.

14 A legis actio per pignoris capionem consistia na concretização de um penhor, efetuado pelo credor mediante a pronúncia de determinadas palavras. Cabia em casos restritos, por força dos costumes e, em outros, por determinação legal. Foi instituída pela Lei das XII Tábuas contra quem comprasse a vítima dada em sacrifício sem lhe pagar o preço e também contra quem não pagasse o aluguel de animal de carga para aplicar-lhe o preço nos sacrifícios religiosos. Pela lei reguladora da função dos censores, também se facultou a pignoris capio aos cobradores de impostos contra as pessoas que, por força de alguma lei, devessem ao fisco (Gaio, I., 4.26-29).

15 Tucci e Azevedo observam com proficiência que o sistema das legis actiones era um sistema de ações antes que um sistema de direitos subjetivos, uma vez que estes não se configuravam pelo aspecto de seu conteúdo substancial, mas, sim, pela ótica das ações com as quais os titulares podiam tutelá-los contra possíveis 
Tábuas $^{16}$ e, depois, em outras leis. Os seus procedimentos eram caracterizados por um rígido formalismo, solenidade, oralidade, simbolismos e rituais. O princípio fundamental em que descansava essa atividade primeva consistia em que o menor equívoco das partes ao pronunciar as fórmulas solenes, constitutivas de qualquer ato processual, implicava a perda do poder correspondente e, algumas vezes, até a da causa (OLIVEIRA, 1997, p. 12/16). Nas Institutas, Gaio exemplificava esse rigorismo referindo que perdia a causa aquele que, num caso de videiras cortadas, empregava o termo videiras ao invés de árvores, porquanto a Lei das XII Tábuas, na qual se fundamentava a ação, empregava a expressão "árvores cortadas" (Gaio, I., 4.11). ${ }^{17}$

$\mathrm{Na}$ qualidade de único detentor da potestas publica, era o rei quem exercia $a b$ initio o papel de iudex, julgando em única instância os litígios. ${ }^{18}$ Essa concentração de poder justificava-se pelo fato de que o rei era considerado uma designação dos deuses, sendo a imagem viva de Júpiter, o deus da Roma. ${ }^{19}$ Nesse contexto de forte influência religiosa, ninguém melhor do que ele para saber a vontade dos deuses diante de um conflito de interesses entre os "mortais". Com a queda da realeza e a instituição da República, ${ }^{20}$

ofensas. Tanto é assim que os romanos anunciavam, ao agere, que tinham uma ação, e não um direito (2001a, p. 45-46).

16 Segundo a tradição, foi um tribuno da plebe, Terentílio Arsa, quem teria proposto a organização de uma comissão em 462 a.C. para redigir leis que pusessem fim às lutas entre o patriciado e a plebe, bem assim os arbítrios dos cônsules. Após muita protelação do senado e dos cônsules, uma viagem à Grécia de uma comitiva a fim de estudar as leis de Sólon, foi instituído um decenvirato que, sob a presidência de Ápio Cláudio, teria elaborado dez tábuas da lei e, depois, mais duas, culminando na Lei das XII Tábuas. Este marco legislativo, aprovado e imposto no ano de 455 a.C., traz em sua tábua primeira relevantes regras de natureza processual, sobretudo quanto ao chamamento ao juízo do réu. Sobre a Lei das XII Tábuas, recomenda-se, por tantos, MEIRA, Sílvio A. B. História e fontes do direito romano. São Paulo: Saraiva, 1966, e MEIRA, Sílvio A. B. A lei das xii tábuas: fonte do direito público e privado. Belém: [s.n.], 1956.

17 Gaio foi um professor de direito em Roma no século II. Ele escreveu, de forma clara e didática, um comentário em quatro livros (Institutas), a fim de que servisse de compêndio para o estudo do direito no primeiro ano das escolas em Roma e, particularmente, nas províncias, até a reforma do ensino promovida por Justiniano nos meados do século VI. Os Gai institutionum commentarii quattuor consubstanciam uma das principais fontes jurídicas autênticas pré-justinianéias, mormente para o estudo do Processo Civil Romano, uma vez que seu quarto livro dedica-se a vários institutos processuais e da praxe jurídica observada nas épocas arcaica e clássica (TUCCI; AZEVEDO, 2001a, p. 31-32). Sobre a biografia de Gaio, veja-se COSTA, Moacyr Lobo da. Gaio: estudo biobibliográfico. São Paulo: Saraiva, 1989.

18 O conceito de imperium não pode ser confundido com o de jurisdicitio. Ajurisdictio consiste em um aspecto do imperium, que significa o poder de comandar e de recorrer à força de que são investidos todos os grandes magistrados romanos (L. 32, De inj., XLVII, 10-L.L. 214 e 215. De verb. Sign. L. 16). Quando a jurisdictio se contrapõe ao imperium, é porque esta toma uma significação mais restrita e exclui os poderes relativos à administração da justiça civil (ACCARIAS, 1886-1891, v. 2, p. 646-647).

19 O poder do rei era considerado o reflexo absoluto do poder de Júpiter (GRIMAL, 2003, passim).

20 Foram setes os reis romanos: Rômulo, Numa, Tullus Hostilius, Ancus Martius, Lúcio Tarquínio, Servius Tullius e Tarquínio, o Soberbo. A realeza ruiu em um momento de instabilidade política, tendo como estopim um estupro praticado pelo filho de Tarquínio, que se refugiou em Chiusi. Ante a crise e a fuga do rei, os senadores tomaram o poder, tendo o povo aceitado a instituição do regime republicano. Embora a chefia de governo pertencesse a dois cônsules eleitos entre os patrícios, eram os senadores que na prática sucederam o rei em face de seus poderes e prerrogativas. 
este poder foi assumido pelos dois cônsules (ENGELMANN, 1927, p. 254; COSTA, E., 1920, p. 135) eleitos anualmente entre os patrícios pela Assembleia dos Centúrias, assembleia popular controlada pela nobreza. Eram os chefes de Governo, cumprindolhes não apenas o conhecimento dos litígios, mas também a iniciativa de criação das leis. Supõe-se que, em decorrência do rápido desenvolvimento da riqueza, do comércio e de outros setores da vida social de Roma, o número e complexidade dos litígios privados tornaram imprescindível a criação de magistraturas com específicas funções jurisdicionais (TUCCI; AZEVEDO, 2001a, p. 42). ${ }^{21}$ Com a distribuição da iurisdictio entre diversos magistrados a partir da República, notadamente entre patrícios, ou seja, entre os integrantes das famílias em que tradicionalmente se recrutavam senadores, integrantes da aristocracia rural, nasce a figura do pretor. ${ }^{22}$

A atuação do pretor era bastante limitada, para além da restrição imposta pelo rígido formalismo próprio do sistema das ações da lei. Não compreendia as suas funções o julgamento do litígio, tal como o faziam o rex e, após, os cônsules. A iurisdictio conferida ao praetor consistia somente no poder de declarar a norma jurídica aplicável no julgamento. ${ }^{23}$ Quiçá com uma forma de mitigar a novel delegação da iurisdictio, houve uma divisão da função de julgar os litígios entre dois órgãos, dicotomizando, assim, o

${ }_{21}$ Os dois cônsules, co-chefes de governo, eram chamados de Magistrados Epônimos, consistindo na primeira espécie de magistratura. Concentrava o mando militar, o controle da polícia interna e da segurança pública, o gerenciamento dos serviços estatais e do funcionalismo público, a gestão do erário ou tesouro público, e, finalmente, a administração da justiça e o exercício da atividade jurisdicional. Em razão do acúmulo de atribuições, do progresso de Roma e da conquista de novos territórios, a pressão política da plebe, entre outros fatores, os cônsules-patrícios foram obrigados a delegar poderes paulatinamente. Assim, o Consulado é desmembrado, surgindo, pouco a pouco, uma série de novas magistraturas, tais como a Questura, a Censura, a Edilidade, a Ditadura, o Tribunato da Plebe e a Pretura, esta para administrar a justiça em matéria fundamentalmente civil, dirimindo conflitos entre romanos (MARCHI, p. 3-19). Sobre as magistraturas romanas desde a monarquia, veja-se MOMMSEN, Theodor. Compendio del derecho publico romano. Buenos Aires: Impulso, 1942, p. 113 e ss.

22 Baseado nos depoimentos de Dionisio de Halicarnasso e Aulo Gélio, sustenta Fustel de Coulanges, em La cité antique, que o rei Servius Tulliu (578-534 a.C.) - escravo e filho adotivo do rei Lucio Tarquínio que foi alçado à condição de rex -, teria instituído os pretores, ao promover a distinção entre as causas públicas e privadas e reservar para si o imperium apenas sobre as causas de natureza criminal. Contudo, de acordo com outras fontes, muito provavelmente o pretor surgiu durante a República, quando houve a divisão de instância. Dionísio (X, I) e Pompônio (D. I, II, § 16) fazem alusão aos poderes dos cônsules como sendo semelhantes aos dos reis (MEIRA, 1971, v. 2, p. 653).

23 Sendo a iurisdictio uma manifestação da potestas publica, não constituía poder autônomo, mas uma função de natureza administrativa. Como destaca Engelmann, aos pretores foi transferido o imperium mixtum: "the 'jurisdictio' was thereupon delegated to the praetor. As, however, he possessed not alone the 'jurisdicio' but with it also the 'imperium', a distinction came to be made between 'imperium merum' and 'imperium mixtum'. 'Merum imperium', according to Ulpian, is: 'habere gladii potestatem ad animadverndum in facionorosos homines, quod etiam potestas appellatur', - hence criminal jurisdiction. That which was conferred upon the praetor was the 'mixtum imperium, quod jurisdictini cohaeret', 'cui etiam jurisdictio inest', - thus, a power which is associated with and embraces 'jurisdictio'. It results from this contrast that ‘jurisdictio’ signifies only civil jurisdiction” (ENGELMANN, 1927, p. 254). 
Processo Civil romano em duas fases. Havia uma primeira fase chamada in iure, perante o pretor, e uma segunda denominada apud iudicem, perante o iudex unus, um cidadão romano que atuava como árbitro. ${ }^{24}$ Apenas quando o objeto da controvérsia versava sobre posse ou sucessão hereditária, a fase apud iudicem ocorria junto aos tribunais dos centumviri, e não perante o iudex unus. Era na segunda fase do processo, da qual não participava o pretor, que se dava o julgamento.

$\mathrm{Na}$ fase in iure das ações da lei, cumpria ao autor exercer a sua pretensão perante o pretor, indicando a respectiva actio. Diante do pedido, o pretor aprazava uma audiência para ouvir as partes. A convocação do réu para comparecer no comitium ou no forum, mediante a in ius vocatio, era responsabilidade exclusiva do autor (Gaio, I., 4.183), sendo que a presença do réu na audiência constituía pressuposto para a continuidade da actio, salvo na diferenciada legis actio per pignoris capionem, a qual se efetivava sem a presença do magistrado e, não raro, do próprio réu. ${ }^{25}$ A Lei das XII Tábuas previa que o autor deveria inclusive prender o réu, perante testemunhas, caso ele não comparecesse na audiência (XII Tábuas, 1.2). Na hipótese de tentativa de engano ou fuga do réu, o autor deveria segurá-lo, conduzindo-o de forma forçada ao pretor (XII Tábuas, 1.3). Posto que pareçam reprováveis tais previsões nos dias de hoje, a importância que se atribuía ao contraditório representava evidente avanço considerando a realidade daquela época. ${ }^{26}$

$\mathrm{Na}$ audiência, as partes manifestavam as suas posições perante o pretor por meio do emprego de fórmulas verbais solenes e previamente estabelecidas, de acordo com a respectiva ação da lei. Se o réu não resistisse à pretensão, reconhecendo a veracidade de suas alegações (confessus), ou na hipótese de as partes acordarem antes da audiência, ${ }^{27}$ o litígio estava resolvido. No caso de confessus, procedia-se de imediato

24 Na legis actio per iudicis arbtrive postulationem, não era escolhido um iudex, mas um arbitrer para a fase apud iudicem quando tinha por objeto a partilha de herança ou a divisão de coisa comum. Como ressalvam Tucci e Azevedo, dada a natureza da ação nesses dois casos, a tarefa do julgador não se restringia à aplicação das normas jurídicas, mas à medição e à avaliação de glebas de terra, de animais e de vários outros bens que compunham o patrimônio a ser dividido, o que reclamava experiência e conhecimento extrajudicial (2001a, p. 67).

25 Conforme Gaio (I., 4.29), por se realizar perante o pretor, havia celeuma entre os juristas romanos sobre a classificação da pignoris capio como ação da lei: “(...) o penhor se efetuava, pronunciando-se determinadas palavras, motivo pelo qual muito achavam que fosse também uma ação da lei. Outros, porém, entendiam o contrário, em primeiro lugar, pelo fato de a pignoris capio realizar-se extra ius, isto é, sem a presença do pretor, e, muitas vezes, até na ausência do adversário, enquanto as demais ações somente poderiam ser propostas perante o pretor na presença do réu. Depois, porque se podia realizar o penhor também nos dias nefastos, isto é, quando não era permitido mover a ação da lei”.

26 Sobre a in ius vocatio, veja-se AZEVEDO, Luiz Carlos de. O direito de ser citado: perfil histórico. São Paulo: Resenha Universitária, 1980.

27 A importância da transação estava claramente expressada na Lei das XII Tábuas, que previa na sua Primeira Tábua, item 8, que "se as partes encontram em acordo em caminho, a causa estaria encerrada". A continuidade da actio só acontecia em caso de fracasso na composição, uma vez que "nita pactum, in comitio aut in fora ante medidiem causam conscito". Por conta disso, é possível supor que o próprio pretor 
a execução, mediante o provimento de addictio, pelo pretor, da coisa reivindicada ou do próprio réu em se tratando de procedimento in personam. ${ }^{28}$ Poderia ainda o pretor denegar a ação (denegare legis actionem), caso a situação jurídica que se pretendia tutelar não se enquadrasse em nenhuma das ações, o réu não comparecesse na audiência, houvesse algum equívoco na realização do ritual formalístico previsto em lei, ou a mesma ação já tivesse sido aforada anteriormente. ${ }^{29}$

Remanescendo a lide, aprazava-se um novo colóquio no prazo de 30 dias, mais uma vez frente o pretor (a partir da Lei Pinária). Não comparecendo uma das partes na audiência, o próprio pretor julgava causa depois do meio-dia favoravelmente àquela que se apresentasse (XII Tábuas, 1.10). Comparecendo ambas, o pretor se cingia a conduzir a fixação dos termos da controvérsia e a determinar o cidadão romano que atuaria como iudex na fase apud iudicem. Na maior parte dos casos, a escolha se dava pela vontade comum das partes; residualmente, por indicação do pretor ou por sorteio dentre aqueles cidadãos constantes do álbum existente no fórum. Por fim, era celebrada a litis contestatio, que encerrava a fase in iure. A litis contestatio consistia no chamamento dos presentes como testemunhas das declarações já feitas, pedindo-se-lhes que conservassem tais declarações na memória para proferi-las perante o iudex. Desse modo, vincularia definitivamente as partes às declarações prestadas e impediria que a questão já deduzida voltasse a ser proposta, visto que as declarações integravam o compromisso de submissão ao decisum a ser proferido pelo iudex (SURGIK, 1990, p. 64; 2001, p. 153-157). Eram, pois, essas testemunhas que garantiam os termos do litígio fixados ${ }^{30}$ e a res acta. ${ }^{31}$

Três dias após a segunda audiência, as partes compareciam perante o iudex nomeado. Inicialmente, autor e réu faziam um breve apanhado da causa a fim de inteirar o

pudesse conciliar as partes.

28 Tucci e Azevedo concluem proficientemente que as ações da lei de natureza cognitivas nascem como forma de oposição aos atos executivos de natureza privada, haja vista que as ações mais antigas - per sacramentum in rem e manus iniectio - iniciavam-se por atos tipicamente executivos em época primitiva. Na primeira, o demandante se apoderava da coisa, objeto do litígio, e a portava perante o magistrado, ou, tratando-se de bem imóvel, tentava adentrá-lo; na segunda, ou seja, na manus iniectio, o autor, poderia agarrar o réu e conduzi-lo à força ao tribunal (2001a, p. 52-53).

29 Veja-se PUGLIESE, Giovanni. Il processo civile romano. Roma: Ricerche, 1961-2. v. 1: Le legis actiones, p. 381.

30 Os romanos atribuíam enorme importância para a determinação do litígio. Fazia-se a litis contestatio convidando os cidadãos que se encontravam no tribunal para que recordassem exatamente o que havia acontecido na sua presença. Esta é justamente a causa pela qual cada parte se fazia acompanhar por seus parentes e amigos (ARANGIO-RUIZ, 1945, p. 28-29).

31 Dentre os importantíssimos efeitos decorrentes da litis contestatio, a novatio necessaria ensejava a extinção da relação de direito material (obrigação originária) deduzida em juízo, dando origem a uma nova relação (obrigação processual derivada), o que vedada, por força da bis de eadem re ne sit actio, o ajuizamento de outra ação lastreada na mesma relação jurídica substancial. $\mathrm{O}$ óbice à propositura de nova ação era declarado com a denegatio actionis pelo pretor, mediante simples prova, levada a cabo pelo magistrado, de que a mesma relação de Direito material já havia sido trazida a juízo (TUCCI, 1993, p. 29). 
iudex e, depois, sustentavam oralmente as suas respectivas razões (peroratio). Concluída a peroratio, produzia-se a prova, sendo admitido como meios probatórios basicamente o juramento, a confissão e, sobretudo, o testemunho. Após a instrução, o iudex julgava soberanamente em nome do povo romano, sem subordinação a qualquer órgão postado em superior grau hierárquico (TUCCI; AZEVEDO, 2001a, p. 44). Aplicando a regra de o onus probandi incumit ei qui dicit no qui negat, proferia sententia sem qualquer fundamentação. Cingia-se a declarar justo (iustum) ou injusto (iniustum) para indicar o vencedor, não cabendo qualquer recurso contra a sua decisão. Poderia ainda o iudex declarar sibi no liquere (não me parece claro) ou se escusar de julgar (excusatio). Nestes casos, as partes deveriam se reapresentar ao pretor para a escolha de um novo iudex.

$\mathrm{Na}$ legis actio per manus iniectionem, que tinha natureza eminentemente executiva, cabível quando havia o inadimplemento da obrigação originada de sentença ou confessus, a atuação do pretor revelava-se mais importante, não dividindo funções com o iudex. Caso o devedor não cumprisse sua obrigação, nem oferecesse um vindex parente ou amigo do devedor que intervinha em seu favor, garantindo, em nome próprio a obrigação ${ }^{32}$, o pretor determinava a manus iniectio. Ele próprio admitia a versão do credor ao pronunciar a palavra addico, autorizando-lhe a exercer seu direito sobre a pessoa do devedor insolvente (manus iniectionem) ou sobre os seus bens (missio in bona rei servandae causae), de acordo com a natureza da causa precedente (TUCCI; AZEVEDO, 2001a, p. 61). Logo, era o pretor quem determinava diretamente os atos executivos.

Em caso de manus iniectionem, o devedor era levado pelo credor e colocado à venda em três sucessivos mercados perante o pretor. Não sendo resgatada a dívida, tampouco comprado o devedor, este poderia ser morto ou vendido escravo aos etruscos pelo credor. ${ }^{33}$ Tais possibilidades resumem bem o quão eram primitivas e, às vezes, cruéis as ações da lei. Ainda que representasse um avanço para a época, em especial pela institucionalização de procedimentos em lei, o sistema das legis actiones tornou-se superado e impeditivo de ulterior progresso com o passar do tempo em virtude de suas limitações. Somado este fato ao exagerado formalismo, foi paulatinamente abandonado, até a sua abolição definitiva por meio das leges Juliae. ${ }^{34}$ As ações da lei permaneceram

32 Após, foram editadas leis prevendo a manus iniectio para outras situações, não decorrentes da coisa julgada. Eram as chamadas manus iniectio pura, as quais permitiam que o próprio devedor se defendesse pessoalmente, sem a necessidade de indicação de um vindex (Gaio, I., 4.23-24).

33 Em 326 a.C. foi promulgada a lex poetelia papiria, que proibiu a cadeia, o grilhão, a morte ou a venda do devedor como escravo, passando a admitir, em substituição à execução pessoal, que a mesma recaísse sobre o patrimônio do devedor quando fosse ele solvente (TUCCI; AZEVEDO, 2001a, p. 70).

34 Conforme registrou Gaio, as ações da lei tornaram-se "odiosas" em razão do exagerado formalismo, permitindo que perdesse a causa aquele que cometesse um mínimo erro (I., 4.30). 
admissíveis apenas para os casos de ações por dano iminente (damni infecti) e de ações sobre posse ou sucessão hereditária (Gaio, I., 4.31).

\section{A origem do processo formular}

Provavelmente, o processo formular surgiu nas províncias (territórios conquistados por Roma) durante o século III a.C., ou seja, no tempo em que ainda vigoravam as ações da lei, quando os estrangeiros (peregrinos) conquistaram o direito de ser parte nos processos em 242 a.C. (KASER, 1968, p. 356). Definiu-se que nos litígios entre estrangeiros ou entre estrangeiros e romanos cumpria a um pretor (praetor peregrinus) a preparação da causa (fase in iure), ${ }^{35}$ e a uma corte - o tribunal dos recuperatores -, e não a um único árbitro, o julgamento (fase apud iudicem). E como as legis actiones eram admitidas apenas para os cidadãos romanos, os pretores peregrinos passaram a prever, mediante fórmulas, as hipóteses em que os estrangeiros poderiam propor a ação (ou romanos em face de estrangeiros). ${ }^{36}$ Assim, ao assumir o cargo, cada pretor publicava o seu respectivo programa (edito), pelo qual revelava os direitos que seriam tutelados durante aquele ano em que exerceria a pretoria. Passa-se, como se depreende das Instituições de Gaio, de agere per legis actiones a agere per formulas (4.30), daí porque a historiografia moderna convencionou denominar este novo modelo de processo de formulário.

Tendo em vista que o ius civile não se aplicava aos estrangeiros, mas, sim, o ius gentium, os pretores começaram discricionariamente a admitir ações em hipóteses que não previstas no Direito quiritário, isto é, em situações em que os próprios cidadãos romanos não podiam demandar em razão das limitações das ações da lei. Este diferencial tornou-se ainda mais relevante diante das novas relações que surgiam com a natural evolução da sociedade romana, sobretudo pela expansão do comércio. Esta flexibilidade somada ao menor formalismo do procedimento fez com que o processo formulário fosse pouco a pouco tomando o espaço das ações da lei, mesmo nas causas entre os quirites. Assim, entre 149-126 a.C., o processo formulário passou a ser admitido de forma oficial pela lex Aebutia, ainda coexistindo com as ações da lei. Finalmente em 17 a.C., por meio

35 O pretor que tinham competência na urbe, ou seja, em Roma, era designado pretor urbano (praetor urbanus): "La iurisdictio compete nell'età primitiva al Re, ed in seguito ai Consuli; poi, dopo il secolo IV di R., ad un terzo magistrato consolare istituito con la funzione specifica della iurisdictio (praetor urbanus) che ha competenza prima sul territorio dell'Urbs, poi su quello d'Italia; nel quale per altro egli esercita la iurisdictio per mezzo di appositi suoi rappresentanti (praefecti iuri dicundo) residenti in alcune delle più ragguardevoli città (praefecturae), mentre per le minori controversie nelle singole città la iurisdictio è rimessa ai magistrati locali (duoviri iuri dicundo)" (COSTA, E.,1918, p. 15-16).

36 A versão aqui exposta não é pacífica. Há romanistas que defendem a tese, v.g., F. L. Keller, de que o procedimento formular teria sido criado em Roma, pelo pretor urbano, como natural evolução das ações da lei, com base no poder de imperium. 
da lex Julia iudiciorum privatorum, o imperador Otaviano Augusto aboliu de vez as legis actiones e instituiu o processo formulário como o rito ordinário para fazer valer todas as classes de pretensões (KASER, 1968, p. 357).

Dessarte, o processo formulário ou formular sobreveio como uma alternativa mais moderna em relação às ações da lei, por ser menos formalista e mais ágil e funcional do que aquele, sendo grande parte dessa evolução fruto do denominado ius honorarium, isto é, do Direito pretoriano. Amparando-se, em princípio, nos fundamentos do ius civile, conservando deste a objetividade e a precisão, trouxe o direito honorário um novo sentido ao processo e à organização judiciária, dilatando o espectro da proteção individual e fornecendo a flexibilidade necessária à melhor distribuição da justiça (TUCCI; AZEVEDO, 2001a, p. 79). O processo formular não era formado por diferentes formas de ação, mas por um rito padrão, o qual, embora também fosse igualmente bipartido instância in iure, perante o pretor, e apud iudicem, perante o iudex -, não exigia uma segunda audiência para a designação do iudex, tal como era imposto pela lex Pinaria para as ações da lei. Representaram significativos progressos a utilização parcial da escrita, a participação mais intensa do pretor e das partes nos atos procedimentais e a instituição da natureza condenatória das sentenças, mesmo nas ações reais (TUCCI; AZEVEDO, 2001a, p. 76-78).

\section{4. $\quad$ O procedimento in iure}

O procedimento in iure do processo formulário principiava pela editio formula, consistente na comunicação prévia do réu pelo autor, oralmente ou por escrito, mediante a entrega de um instrumentum com esse fim, da pretensão (intentio). Tratava-se de ato extraprocessual preliminar que deveria preceder a in ius vocatio. Caso não fosse observada a referida formalidade, a ação seria indeferida pelo pretor. Procedida à editio formula, o autor deveria realizar a citação do réu, sendo-lhe defeso concretizá-la doravante com o emprego da força. Caso o réu não comparecesse em juízo, nem fornecesse um vindex, o pretor tinha o poder de conceder ao autor uma actio in factum. ${ }^{37}$ Substitui-se a primitiva violência, ficando, todavia, o réu sujeito ao pagamento de multa, à penhora e até à perda de seus bens caso insistisse em não se apresentar (TUCCI; AZEVEDO, 2001a, p.

37 Caso o réu comparecesse, mas não fosse possível o julgamento no mesmo dia, ele deveria prestar vadimonium, isto é, comprometer-se a comparecer no novo dia aprazado pelo pretor. Em alguns casos, era necessária caução ou juramento (Gaio, I., 4.184-185). Posteriormente, o vadimonium desvirtuou-se de tal maneira que passou a substituir a in ius vocatio em inúmeras hipóteses, permitindo que o processo iniciasse pela promessa do réu de que compareceria em juízo. A propósito, o vocábulo vadimonium é abarcado pelo romanista Emilio Costa no interessante ensaio Il diritto nei poeti di Roma. Bologna: Ditta Nicola Zanichelli, 1898, em que trata de expressões jurídicas empregadas em poemas romanos da época (p. 15-16). 
80-81). ${ }^{38}$ É provável que, além de impor sanções ao réu que não comparecesse em juízo nem indicasse um vindex, fosse também função do pretor observar a realização da edito formula, da in ius vocatio e a admissão do vindex indicado pelo réu.

Presentes as partes perante o pretor, por si ou acompanhadas por seus respectivos advocatus, ${ }^{39}$ deveria primeiramente o autor formalizar a sua pretensão (editio actionis), designando a fórmula do edito em que se embasava a sua pretensão (postulatio actionis). Feito isso, cumpria ao pretor verificar se a intentio estava de fato contemplada em seu edito e se reunia os pressupostos, materiais e processuais. Não estando prevista no edito ou faltando algum pressuposto, bem como nos casos em que a mesma relação jurídica processual já havia sido objeto de ação anterior (bis de eadem re ne sit actio), o próprio pretor denegava a ação (denegatio actionis). De outra parte, não se enquadrando nenhuma dessas hipóteses, o pretor deferia o pleito preambular do Autor, abonando a continuidade do processo (datio actionis). Essa decisão do pretor de "conceder a ação ao Autor", ou seja, de reconhecer o seu direito de mover a actio contra o réu, constituía verdadeiro juízo de admissibilidade. ${ }^{40}$

Deferida a ação, oportunizava-se ao réu proceder à sua defesa. Era-lhe lícito tanto realizar a defesa material como a processual, bem como formular um pedido autônomo relacionado ao mesmo negócio jurídico em questão nos casos de ações bona fidei (iudicium contrarium). Neste caso, o processo assumia natureza dúplice, passando ambas as partes a ser, concomitantemente, autor e réu. Na hipótese em que o réu reconhecia o direito do autor a um crédito certo (confessio in iure), sua manifestação equivalia a uma condenação. ${ }^{41}$ Não havia necessidade de sentença, conferindo-se ao autor o direito de propor a actio iudicati se não houvesse o pagamento. E equiparava-se ao réu confesso o que não comparecia em juízo para se defender ou o que não se defendia quando comparecesse (indefensus). O réu também era considerado como se condenado fosse na

38 O autor poderia ainda teoricamente usar da força para conduzir o réu até o pretor, embora, na prática, devesse ser mais comum a solicitação de uma ação in factum contra o réu, para que fosse condenado a pagar ao autor uma multa (ALVES, 1978. v. I, p. 295).

39 Passou-se a admitir no processo formulário a representação processual (Gaio, I., 4.82-84) e jurídica. Kaser esclarece que tanto o autor como o réu poderiam ser representados por um cognitor, representante nomeado publicamente e na presença da parte contrária ou por um procurator, representante não designado dessa forma. Havia também o tutor, o curator e um órgão facultado legalmente a ostentar a representação processual de corporações e município. Ademais, as partes poderiam ser assistidas por oratores, patroni advocati, que colaboravam com os seus conhecimentos técnicos na fase in iure do processo e com as suas faculdades oratórias na fase apud iudicem (KASER, 1968, p. 369-370). Veja-se COSTA, Emilio. Profilo storico del processo civile romano. Roma: Athenaeum, 1918, p. 121-131.

40 DIAS, Handel Martins. A evolução dos poderes do pretor na história do processo civil romano. Intertemas: Revista da Toledo, Presidente Prudente, p. 205-225, v. 15, 2010, p. 214.

${ }^{41}$ Nos casos em que a confessio fosse sobre valor indeterminado e não houvesse a indicação da soma na confissão, esta não equivalia ao reconhecimento do pedido. Nesta hipótese, era dado prosseguimento ao processo, constituindo a confissão mero meio de prova. 
hipótese em que o autor requeria o juramento de dívida e ele não jurava a sua inexistência. Em todos esses casos, o pretor determinava, de imediato, o cumprimento da obrigação cobrada pelo autor no prazo de trinta dias.

Apresentada a defesa pelo réu, era o momento de se designar o iudex (apenas nas causas entre estrangeiros ou entre estrangeiros e romanos o julgamento da causa tocava ao tribunal dos recuperatores). A escolha do cidadão romano que julgaria a causa, de ordinário dentre aqueles integrantes do album iudicium, era feita conjuntamente entre os sujeitos processuais, sendo que o pretor não tinha, como dantes, o poder de impor às partes a sua vontade. Se houvesse recusa de uma indicação, fosse proveniente de uma das partes ou do pretor, outra deveria ser realizada, até que se alcançasse consenso sobre a pessoa que deveria desempenhar aquele munus. Escolhido o iudex unus, passava-se à redação da fórmula. Consistia num documento escrito, elaborado pelo pretor conjuntamente com as partes, em que se fixava o objeto da demanda, definindo os limites do litígio. ${ }^{42} \mathrm{~A}$ fórmula deveria ser levada ao iudex eleito para o julgamento da controvérsia, ficando vinculado aos seus temos. ${ }^{43}$

Concluída a redação da fórmula, era chegado o momento da litis contestatio, isto é, de as partes comprometerem dar prosseguimento à contenda nos termos e nos limites expressados na fórmula, bem como a se submeter ao julgamento que fosse proferido pelo iudex. Assim, efetivada a litis contestatio, o pretor providenciava a translatio do iudicium, para que o processo prosseguisse na fase apud iudicem. ${ }^{44}$ Não era mais possível a propositura de nova ação fundada na mesma relação jurídica substancial (bis de eadem re ne sit actio) ${ }^{45}$ tampouco a modificação da fórmula. Apenas excepcionalmente, quando fosse imprescindível a modificação dos elementos objetivos da lide, era possível a redação de nova fórmula, a qual era concedida ao interessado pelo pretor, no bojo de outro processo, mediante a restitutio in integrum. E embora permanecesse sendo mister

42 Eram quatro as partes formularum, a saber, a intentio (em que o autor expõe a sua pretensão), a demonstratio (em que traz elementos para se determinar o quidquid nos casos em que a intentio é incerta), a adjudicatio (em que se permite ao juiz adjudicar a coisa a alguma das partes) e a condemnatio (em que se dá ao iudex o poder para condenar ou absolver o réu). Contudo, ressalva que "this does not mean that every formula must have all these parts, or that it may not have other parts, by way of addition. But the four mentioned are the regular parts of the formula" (ENGELMANN, 1927, p. 288-294).

43 Sobre o ônus probatório no processo formular, veja-se PUGLIESE, Giovanni. Regole e direttive sull'onere della prova nel processo romano per formulas. In: Scritti giuridici in memoria di Piero Calamandrei, Padova: CEDAM, 1958. v. 3, p. 577-617.

44 Tanto sobre o procedimento in iure como do procedimento apud iudicem do processo formular, é imprescindível a leitura de PUGLIESE, Giovanni. Il processo civile romano. Milano: Giuffrè, 1963. v. II: Il processo formulare, p. 259 e segs.

45 A litis contestatio importa a consumação do direito deduzido na lide e a novação de tal direito em outro de obter, em caso de êxito do iudicium, a condenação do demandado na soma de dinheiro que constitui seu objeto. Por isto, depois da litis contestatio, o autor não pode mais repropor o mesmo direito (SURGIK, 2001, p. 154). 
do iudex o julgamento da causa, o pretor passou a ter influência também na fase apud iudicem. Além de contornar os limites da causa ao redigir a fórmula com as partes, o pretor passou naturalmente a exercer uma supervisão do processo, podendo prestar informações complementares e determinar medidas incidentais, além de determinar, conforme o caso, a alteração do iudex ou de uma das partes (TUCCI; AZEVEDO, 2001a, p. 108).

\section{O procedimento apud iudicem}

Observando as escassas fontes que tratam da fase apud iudicem, constata-se que não houve alteração significativa comparativamente com o procedimento das ações da lei. As partes compareciam, em princípio três dias após a efetivação da litis contestatio, no fórum ou no comitium perante o iudex, que deveria prestar juramento. O litigante que não comparecesse até o meio-dia perdia a causa, como previsto na Lei das XII Tábuas. Apresentando-se ambas as partes, elas expunham brevemente a causa, pessoalmente ou por meio de um representante ou de seu advogado, e o iudex examinava a fórmula. Em sequência, realizava-se a instrução a fim de se provar os fatos da causa. A rigor, não precisavam as partes provar a existência e a eficácia o direito em que se amparavam (iura novit curia), somente os fatos respectivamente alegados, vigorante a regra no sentido de que ei incumbit probatio qui dicit, non qui negat. Além de documentos e de testemunhos, principais meios de prova, admitiam-se ainda precedentes, opinião pública, tortura, confissão e o juramento.

Concluída a instrução, falavam os advogados das partes mediante retórica por até uma hora. Eram autênticos discursos em que os advogados tratavam sobre tudo o que havia ocorrido até aquele momento. ${ }^{46}$ Encerradas tais manifestações e formada a convicção, ${ }^{47} \mathrm{o}$ iudex pronunciava a sua decisão oralmente e na presença das partes

46 Já desde os tempos republicanos, era, sobretudo, neste momento que costumavam atuar os defensores e retóricos, fazendo uso da palavra em tempo não superior a uma hora, segundo notícia das leges Iuliae. Estas alegações verbais, de onde, ocasional e historicamente, nasceu e se desenvolveu a retórica romana, constituíram autênticos discursos, que tradicionalmente vinham divididos em várias partes: exordium, narratio, partitio, confirmatio, reprehensio ou refutatio e, por último, a conclusio. O exordium consistia em uma mera invocação oratória, normalmente muito breve, enquanto a narratio ou exposição dos fatos podia se mais longa. Depois da divisão ou classificação - partitio - dos diversos pontos em que se baseava a alegação, vinha a refutatio, encerrando todo o discurso oratório na conclusio final (SURGIK, 1990, p. 69).

47 Como no período do direito arcaico, poderia o iudex se abster julgar se formasse uma convicção, pronunciando sibi non liquere. Depoimentos riquíssimos encontram-se na obra Noites Áticas, de Aulo Gélio, especialmente no Livro XIV, II. Aulo Gélio, que atuou como iudex durante o período do processo formulário, mais precisamente no século II d.C., narra no mencionado livro uma valiosa experiência pessoal em uma dada cobrança de dívida para a qual foi nomeado iudex. O autor, "varão firmemente de bem e de conhecida e comprovada boa fé e de vida impecabilíssima" cobrava dinheiro de um "homem não de bom valor, de vida torpe e sórdida, provado publicamente em mentiras, pleno de perfídias e de fraudes", sem, contudo, provar as suas alegações. Consultado um consílio, formado por "varões exercitados e célebres nas defesas e nas atividades do foro, e que sempre se apressam sob causas que os demandam de todos os lados", 
(pronuntiatio), podendo, antes disso, consultar um consilium. Diferentemente do que ocorria no âmbito das ações da lei, no qual o juiz estava vinculado ao resultado da prova, vigorava no processo formular a livre convicção. Pois, embora limitado aos termos da fórmula, o iudex dispunha de discricionariedade para formar a ratio decidendi, sem, contudo, precisar motivar sua decisão, que se cingia a colher ou rejeitar a intentio do Autor: condemnatio ou absolutio. ${ }^{48}$ A sentença de procedência era sempre condenatória, mesmo quando reconhecido direito real, fazendo nascer uma nova relação jurídica entre os litigantes. É essa nova relação, denominada res iudicata, que servia de fundamento para a actio iudicati caso não houvesse o pagamento (TUCCI; AZEVEDO, 2001a, p. 126-128).

Conquanto não coubesse recurso contra a sentença, poderia o réu derrotado negar-se a cumprir a obrigação, forçando o credor a deduzir uma nova ação, a actio iudicati, na qual poderia se defender por meio da infitiatio. Predomina entre os romanistas modernos que o condenado poderia também tomar a iniciativa, deduzindo, antes que o credor intentasse a actio iudicati, uma ação autônoma de origem pretoriana denominada revocatio in duplum, pela qual requeria a revogação do julgado sob a alegação de nulidade. A revocatio in duplum teria, portanto, natureza de ação especial, destinada a negar a existência da sentença como tal, com a índole da moderna ação declaratória negativa, que visa à declaração da nulidade do julgamento e não à rescisão da sentença para a desconstituição de seus efeitos. Caso fosse rejeitada a revogação de sentença, o devedor era condenado, a título de sanção, a pagar o dobro da quantia à qual havia sido obrigado anteriormente (COSTA, M., 1995, p. 14-18).

Poderia ainda a parte perdedora propor a restitutio in integrum para desconstituir a sentença. A restitutio in integrum consubstanciava-se em uma tutela de

afirmaram "não haver dúvida que houvesse de ser absolvido aquele que se mostrava não ter recebido dinheiro por nenhuma prova habitual". Ainda não convencido, Aulo Gélio adiou o dia da prolação da sentença para consular o filósofo grego Favorino [além de gramática e retórica em Roma, Aulo Gélio estudou filosofia em Atenas e era discípulo de Favorino]. Após digressões filosóficas, o sofista grego aconselha: "deposites confiança naquele que reclama e condenes aquele de quem se reclama, pois que, assim como dizes, os dois não são iguais e quem pede é melhor". Sem convicção de que julgaria justamente ao absolver o réu em razão inexistência de provas ou ao condenar o réu com base apenas em seu conhecimento privado, Aulo Gélio declarou o sibi non liquere e se absteve de julgar aquela causa: "eu estimei isto ser maior e mais alto do que o que à minha idade e mediocridade conviesse: que eu parecesse ter investigado e ter condenado a partir dos costumes, não a partir das provas do fato gerado; que eu absolvesse, todavia, não me pude induzir ao ânimo, e por isso assegurei não me ser clara a causa, e assim fui desligado daquele julgamento (GÉLIO, 2010, p. 483-486).

48 Uma vez formada a sua convicção, o iudex deveria deduzir as consequências previstas na fórmula, absolvendo ou condenando o réu. Porém, há situação que o iudex precisa levar a cabo outras atuações para cumprir a fórmula. "Deberá, por ejemplo, invitar al demandado a probar el fundamento de su excepción o a restituir la cosa que es objeto de la reivindicación. Otras veces le será preciso estimar en dinero el objeto del litigio, eventualmente redoblar esa cantidad; etc. Sólo después de estas operaciones podrá el juez pronunciar su sentencia de condena o absolución" (ARANGIO-RUIZ, 1945, p. 103-104). 
natureza preponderantemente desconstitutiva, com o condão de anular atos ou negócios jurídicos, ou ainda sentenças notoriamente injustas, repondo às partes ao estado anterior, ainda que fossem válidos à luz do ius civile. ${ }^{49}$ Eram pressupostos para a restitutio in integrum a existência de justa causa, a ocorrência de dano, a ausência de outro meio processual que pudesse tutelar os efeitos prejudiciais decorrentes do ato impugnado e a formulação do pedido no prazo de um ano. Caso acolhesse os argumentos deduzidos pelo interessado, o próprio pretor rescindia, mediante decreto, o ato impugnado (iudicium rescindens). Porém, caso a restitutio in integrum não fosse suficiente, sendo necessária decisão para redefinir aquela relação jurídica desconstituída, o processo ingressava num novo estágio (iudicium rescissorium). Como de ordinário, era redigida uma fórmula, realizada a litis contestatio e encaminhadas as partes ao iudex. ${ }^{50}$

\section{A actio indicati}

Definida a obligatio iudicati, notadamente nos casos em que o iudex pronunciava a condemnatio, ou ainda na hipótese de confessio in iure durante a fase in iure, o réu dispunha do prazo de trinta dias para efetuar o pagamento, em dinheiro, ao autor (tempus iudicati), conforme estabelecido na Lei das XII Tábuas (Tábua III, n. IV). Este prazo tinha o escopo de conceder ao demandado um tempo para reunir numerário suficiente para o adimplemento do débito. Não sendo pago nesse ínterim, cumpria ao Autor propor nova ação, a actio iudicati, calcada na resistência do réu em pagar a quantia a que foi condenado ou a qual havia confessado perante o pretor, para que fosse cumprida a sentença. Não se tratava, pois, de um processo de execução, mas, sim, dum novo processo cognitivo. Como referem os ilustres professores José Rogério Cruz e Tucci e Luiz Carlos de Azevedo, o período formular não conheceu uma actio de natureza executiva, mas somente atos executivos (2001a, p. 131-132).

O procedimento da actio iudicati era senão o mesmo do processo formulário. Iniciava com a editio formula realizada pelo credor, seguindo-se com a in ius vocatio e o comparecimento das partes diante do pretor, quando o autor formalizava a sua pretensão (editio actionis). Outorgada a ação ao autor pelo pretor (datio actionis), cumpria

49 O Edito do Pretor consignava oito hipóteses em que a restitutio poderia operar-se: 1) menoridade de 25 anos; 2) metus; 3) dolus; 4) error; 5) ausência reipublicae causa; 6) capitis deminutio; 7) alienatio judicii mutandi causa (alienação dolosa com objetivo de alterar as condições da ação a intentar); e 8) cláusula geral para os casos em que parecesse justa ao magistrado a restituição. Os principais casos em que o pretor poderia decretar a restituição por inteiro eram o do menor de 25 anos prejudicado por um negócio ruinoso; o do ausente que perdeu o direito de propriedade por usucapião; a capitis deminutio de devedor; e o ato jurídico praticado com erro, dolo, coação ou fraude a credores (MEIRA, 1971, p. 732).

50 Sobre a restitutio in integrum, veja-se COSTA, Moacyr Lobo da. A revogação da sentença: gênese e genealogia. São Paulo: Ícone, 1995. p. 25-81. 
ao réu prestar uma caução a fim de garantir a satisfação do crédito e realizar sua defesa (infitiatio). ${ }^{51}$ Caso não se defendesse mediante fiança, o pretor de imediato determinava a ordem de execução pela soma cobrada (duci iubere). A defesa do réu basicamente só poderia se cingir à inexistência de condemnatio ou de confessio in iure, a existência de alguma nulidade no processo em que teria sido definida a obrigação ou, ainda, o fato de já ter adimplido a condenação cobrada. Em outras palavras, não se permitia na actio iudicati a revisão da obrigação definida no processo anterior, mas, sim, a verificação de sua existência e da regularidade do procedimento.

Ante a formalização da resistência pelo réu, deveria ser escolhido o iudex, redigida a fórmula e firmada a litis contestatio. Concluída a fase in iure, compareciam as partes perante o iudex eleito para o início do procedimento apud iudicem. Após breve exposição da causa pelas partes, o iudex examinava a fórmula e autorizava a produção de provas. Encerrada a instrução e realizadas as derradeiras manifestações pelos advogados, o iudex proferia sua decisão, absolvendo o réu (absolutio) ou o condenando (condemnatio). Em caso de acolhimento da demanda, o réu era condenado a pagar o dobro da quantia inicialmente prevista a título de sanção pelo descumprimento de sua obrigação (lis infitiatio crescit in duplum). Caso não se contemplasse dolo do réu em sua resistência, era afastada a condenação duplicada. Nesta hipótese, o réu era simplesmente condenado a pagar a mesma quantia à qual estava obrigado.

A diferença fundamental da sentença proferida pelo iudex na actio iudicati era o fato de que consistia em verdadeiro título executivo. Enquanto as sentenças em geral proferidas no processo formular autorizavam apenas a própria actio iudicati em caso de descumprimento da obrigação, a sentenças proferidas nas actiones iudicati ensejavam a realização de atos executivos em caso de não satisfação do crédito. Com efeito, permitia ao credor requerer a posse da totalidade dos bens do devedor, móveis ou imóveis, ao pretor, que, forte em seu poder de imperium, autorizava a imissão na posse (missio in bona rei servandae causa), bem como a posterior publicação de editais (proscriptiones) e alienação dos bens. Caso o patrimônio não fosse suficiente para o pagamento da dívida, era permitido ao credor proceder à execução pessoal contra o devedor. Para não se tornar fraudator e a aplicação da pena de infâmia, ${ }^{52}$ ou bem o devedor oferecia seus bens ao credor antes da missio in possessionem (cessio bonorum), como autorizado na lex Julia, ou bem quitava o débito antes da hasta pública.

\footnotetext{
51 Conforme Tucci e Azevedo, se era certo que o demandado já podia se defender pessoalmente, não sendo mais necessária a intervenção de um terceiro para contestar o pedido do autor como no período das ações da lei, deveria fornecer, a par da infitiatio, uma caução para garantir o cumprimento do julgado (2001a, p. 133).

52 Sobre a pena de infâmia no direito romano, veja-se MAZZACANE, Aldo. Infamia: diritto romano e intermedio. In: Enciclopedia del Diritto. Milano: Giuffrè, 1971. v. 21, p. 382-387.
} 
Caso houvesse mais de um credor ou de não-localização do devedor, a execução do patrimônio (uenditio bonorum) assemelhava-se ao atual concurso de credores. Embora o pretor autorizasse a posse sobre todos os bens do devedor em favor de um único credor, todos aproveitavam. Nomeava-se um administrador provisório dos bens (curator bonorum) e dava-se a adequada publicidade durante trinta dias, ou quinze dias se o executado estivesse falecido. Transcorrido o referido prazo, os credores designavam um magister, o qual, feito o balanço do patrimônio e estabelecidas as condições (lex uenditionis), procedia, após outro termo de quinze ou dez dias, à venda em hasta pública àquele que oferecesse o melhor preço ao patrimônio em bloco. A posição do comprador (bonorum emptor) equiparava-se à de um herdeiro do executado. Sucedia-o em suas situações jurídico-patrimoniais, pagava-lhe as dívidas (até o limite do preço da venda) e cobrava seus créditos (SURGIK, 1990, p. 73).

\section{A atividade criadora do pretor}

O fomento do papel do pretor no exercício da iurisdictio no período formular não se resumiu a tal. O pretor incorporara uma novel e importantíssima competência no exercício da sua função de ius dicere: a de produzir direitos. Ao assumir o cargo, o pretor publicava o seu programa (edito), pelo qual revelava como atuaria durante aquele ano em que exerceria a pretoria, realizando autêntica atividade normativa. Embora sem derrogar as regras do direito quiritário, os pretores começaram discricionariamente a prever direitos que não estavam previstos ou a modificar os já existentes no ius quiritium para solucionarem casos concretos. Isso permitiu que os pretores, forte no seu poder de imperium, denegassem ações mesmo quando as tutelas jurídicas pretendidas estivessem insculpidas no direito quiritário ou, ao contrário, concedessem ações quando as pretensões não estivessem previstas no ius civile. Esse direito produzido e elaborado pelo pretor era chamado de ius honorarium.

Provavelmente por influência da filosofia grega, sobretudo pela ética aristotélica, os pretores passaram a considerar a aequitas (o justo ideal) ao criar essas novas normas jurídicas. ${ }^{53}$ Consoante sublinha Maria Cristina da Silva Carmignani, foi inspirado na aequitas que os magistrados romanos livraram o direito escrito - considerado odioso como atestou Gaio ao tratar do fim das ações da lei - de suas amarras, procurando aproximá-lo do bonum-aequm. Com a formulação de novas regras, inspiradas nesse ideal

53 Segundo Aristóteles, como a lei é incapaz de prever todas as possibilidades, deveria o juiz suprir as suas omissões e corrigir suas eventuais injustiças considerando as peculiaridades do caso concreto. Em suma, como instrumento a aplicação da aequitas (justo ideal), o juiz deveria se valer da equidade (epieikeia) para adaptar ao caso concreto a gene-ralidade da lei ou suprir suas lacunas (ARISTÓTELES, 2001, passim). 
de justiça, que eram introduzidas nos editos e aplicadas dentro do processo formulário, corrigindo, suprindo ou afastando a aplicação do ius civile quando iníquo, os pretores construíram gradativamente uma verdadeira ciência do direito. E para que a decisão refletisse a aequitas, o pretor assinalava na fórmula quais elementos que deveriam ser valorizados pelo iudex, ampliando, para tanto, cada vez mais, por meio de seus editos, as normas e os meios processuais ordinários e extraordinários que poderia se servir na administração da justiça (2009, p. 118-119).

Com efeito, o ius honorarium instituído com o escopo de corrigir iniquidades ou suprir lacunas do antigo direito quiritário não se cingia a tratar do direito subjetivo. Por meio dos editos, os pretores também passaram a determinar a praxe processual, promovendo modificações que considerassem necessárias ou oportunas. ${ }^{54}$ Toda essa atividade criadora do pretor prodigalizou flexibilidade para o sistema e uma evolução da técnica processual. São originárias do direito pretoriano, v.g., a editio actionis, a exceptio rei in iudicium detuctae vel rei iudicatae, a actio in factum e o iudicium contrarium. Inclusive meios processuais complementares de tutela foram criados pelos pretores com o fito de suprir a lacuna existente a partir das novas exigências sociais advindas com o desenvolvimento de Roma, tais como as stipulationes praetoriae, ${ }^{55}$ as missiones in possessionem, ${ }^{56}$ as restitutiones in integrum e os interdicta, os quais poderiam ser proibitórios (proibição da prática de um ato), restituitórios (restituição de alguma coisa ou pessoa) ou exibitórios (exibição de alguma coisa ou pessoa). ${ }^{57}$

Sem embargo da alternância de pretores (o mandado da pretura era anual), o ius honorarium era, em geral, estável. Isso porque os pretores costumavam, ao assumirem

54 Sobre os editos dos pretores e o ius honorarium, veja-se COSTA, Emilio. Storia del diritto romano pubblico. Firenze: Barbéra, 1920, p. 36-44.

55 Era um contrato formal, suscetível a toda a sorte de prestações, da qual se servia o pretor para instituir obrigações jurídicas em hipóteses em que elas não existiam, quando considerava uma situação digna de ser protegida. Assim, dois cidadãos romanos obrigavam-se voluntariamente entre si, perante o pretor, celebrando uma avença verbal (ARANGIO-RUIZ, 1945, p. 28-9).

56 Existia quando o pretor emitia um indivíduo na posse de uma coisa ou de um patrimônio pertencente a outra pessoa. Os romanos falavam de missio in rem quando se tratava de uma coisa determinada e de missio in bona, quando se tratava de todo o patrimônio. Na maioria das ocasiões a emissão na posse era uma sanção imposta a alguém que não tinha obedecido a uma ordem expressa do magistrado (ARANGIO-RUIZ, 1945, p. 112).

57 Os interditos consistiam em tutelas de natureza mandamental. Realizada oralmente a postulatio interdicti, o próprio pretor examinava os fatos alegados e, de plano, mediante cognição sumária, julgava o pedido. Caso denegasse o pedido (denegatio interdicti), a decisão era definitiva. A questão também restava encerrada quando fosse concedido o interdito (editio interdicti) e o mesmo fosse observado pelo réu. Porém, caso não houvesse o cumprimento da ordem, o autor deveria, amparado na decisão do pretor, reapresentar o seu pedido de interdito via processo per formulas ordinário, denominado actio ex interdicto. Assim, o iudex poderia revogar a ordem emanada anteriormente pelo pretor ou ratificá-la. Para Carmignani, a gênese da tutela antecipada é justamente a tutela intedital romana. Veja-se, a respeito: CARMIGNANI, Maria Cristina da Silva. A origem romana da tutela antecipada. 2000. 107p. Dissertação (Mestrado) - Faculdade de Direito, Universidade de São Paulo, São Paulo. (publicada pela editora LTr, em 2001). 
o cargo, manter em seus respectivos editos as regras virtuosas previstas nos programas de seus antecessores, formando, assim, ao longo dos anos, um corpo estratificado denominado edictum tralaticium. Em outras palavras, os pretores aproveitavam as experiências anteriores que haviam sido aprovadas na prática para aplicá-las futuramente em casos semelhantes. ${ }^{58}$ Por outro lado, em casos de lacuna ou de iniquidade de uma determinada regra, poderia o pretor introduzir novas disposições a fim de evolver o próprio direito pretoriano (edictum repentinum). Esta liberdade de que gozou o pretor àquele tempo, advinda como resposta às restrições de fontes do Direito que havia antes e da incapacidade de essas evoluírem, e a atividade dos jurisconsultos ${ }^{59}$ impulsionaram significativamente o Direito Romano, erigindo a outra categoria. Foi neste período em que era eminentemente social, elaborado de acordo com as necessidades da sociedade, que o Direito Romano viveu o seu apogeu (CARMIGNANI, 2009, p. 127).

O declínio da atividade criadora dos pretores inicia ainda no principado, curiosamente pela mesma lei que oficializou o processo formulário, a lex Julia iudiciorum privatorum, prevendo a assunção, pelo príncipe ou por um de seus delegados, ${ }^{60}$ da jurisdição de determinadas causas (cognitio extraordinaria). ${ }^{61 / 62}$ Mas ao encontro do

58 Em O processo civil italiano no quadro da contraposição "civil law"-“common law": apontamentos histórico-comparativos. Traduzido por Daniel Ustárroz e Handel Martins Dias. Revista da Ajuris, Porto Alegre, 2005, n. 100 (edição histórica), p. 409-442, Mauro Cappelletti faz uma interessante comparação entre o processo romano clássico e os dos países de common law. Para ele, há mais afinidades com esses ordenamentos dos países da Europa continental e, em geral, do que nos países de civil law, dentre os quais estão compreendidos, por exemplo, todos os países da América Latina.

59 Conforme José Carlos Moreira Alves, os jurisconsultos exerceram acentuada influência sobre o desenvolvimento do direito romano graças, principalmente, a três aspectos de sua atividade: cauere, agere e respondere. Cauere é expressão técnica que indicava a atuação do jurista no formular e redigir os negócios jurídicos, para evitar prejuízo à parte interessada, por inobservância de formalidades; agere é a atividade - no que concerne ao processo - semelhante à desenvolvida no cauere; e respondere diz respeito aos pareceres dos jurisconsultos sobre questões de direito controvertidas (1978. v. 1, p. 34). Sobre a contribuição dos jurisconsultos, veja-se CARMIGNANI, Maria Cristina da Silva. O direito judiciário na história: a experiência romana e luso-brasileira: utilização como forma de resolução dos anseios sociais por justiça. 2004. 110p. Tese (Doutorado) - Faculdade de Direito, Universidade de São Paulo, São Paulo. p. 3251.

60 A despeito da atribuição de funções delegadas aos seus subordinados, o imperador reservava para si a qualidade de único intérprete do direito e supremo magistrado em qualquer grau de jurisdição, e, portanto, legitimado a reexaminar toda e qualquer decisão judicial (TUCCI; AZEVEDO, 2001a, p. 155).

${ }_{61}$ Está aí a origem da criação do derradeiro sistema processual romano, o da cognitio extra ordinem, que perdurou por mais de quinhentos anos. Ao assumir a competência para julgar determinadas causas, o princeps decidia os litígios em única instância, sem nomear um árbitro para fazê-lo (fase apud iudicem). Com o tempo, este mesmo poder foi conferido aos pretores, eliminando-se definitivamente a bipartição de instâncias. Isso porque, já suficientemente fortalecido, o Estado passou a impor aos particulares, autoritariamente, por meio do pretor, a sua solução para os conflitos, a despeito de qualquer submissão voluntária. Completava-se, assim, o ciclo histórico da transposição da justiça de privada para pública. Sobre a introdução e desenvolvimento do processo da cognitio extra ordinem, veja-se COSTA, Emilio. Profilo storico del processo civile romano. Roma: Athenaeum, 1918, p. 121-131.

62 Com a gradativa oficialização das instituições processuais, em consequência da consolidação da cognitio 
absolutismo total, foi necessário esvaziar o poder dos pretores de criar o direito. Dessarte, por volta de 130 d.C. o Imperador Adriano encarregou o jurisconsulto Sálvio Juliano, chefe da escola dos sabinos, de codificar os editos até então existentes. Sálvio Juliano adotou e escolheu as disposições que lhe pareceram corresponder às necessidades de seu tempo, rejeitando, por outro lado, aquelas que já haviam caído em desuso. O trabalho de composição e coordenação de todos os editos passados, chamado de Edito Perpétuo, foi sancionado pelo senado e se tornou obrigatório (AZEVEDO, 2005, p. 67-68). A partir de então, os pretores ficaram limitados a inserir em seus editos apenas aquelas regras que estivessem contidas no Edictum Perpetuum Salvvi Juliani, sendo-lhes defeso a criação de novas normas, salvo com expressa autorização do princeps ou do senado. ${ }^{63}$

\section{Conclusão}

No início de Roma, a defesa privada teve larga utilização. O Estado antigo romano não tinha força suficiente para suplantar os ímpetos individualistas dos homens e impor-lhes o direito. A mentalidade não admitia a ingerência estatal nos negócios dos particulares, motivo pelo qual se evoluiu do regime da autotutela para o da arbitragem, que perdurou até o Império. Quem sucedeu o Rei, e posteriormente os cônsules durante a República, na missão de julgar os litígios foi um cidadão romano eleito. Naturalmente, a primitividade e a religiosidade influenciaram grandemente o pioneiro sistema processual romano, o das legis actiones. Era um sistema de ações, em que só era lícito demandar quando a ação, ou a situação jurídica que se pretendia tutelar, estava prevista expressamente na lei. Os procedimentos eram caracterizados por um rígido formalismo, solenidade, oralidade, simbolismos e rituais. O menor equívoco das partes ao pronunciar as fórmulas solenes poderia implicar a perda da causa. A precariedade e limitações das ações da lei fizeram com que fossem gradualmente abandonadas, até abolida em definitiva

extraordinaria, o magistrado, agora também juiz, passa a ser o titular do poder-dever de examinar as provas e proferir sentença, a qual, pela primeira vez na história do processo civil romano, não mais consistia num ato exclusivo do cidadão romano, não tinha caráter arbitral, mas, sim, consubstanciava-se numa atuação em que era exprimida a vontade do soberano (ex autoritate principis). Mesmo ainda persistindo a possibilidade de o magistrado, num determinado caso, atribuir funções jurisdicionais a um juiz delegado (iudex datus), a investidura deste deixava de ser subordinada à vontade das partes, uma vez que decorria exclusivamente de ato da autoridade judicial. As vantagens do novo procedimento, a maior autoridade conferida ao juiz e o abandono dos resquícios de formalismo, determinaram a sua expansão, chegando, em pouco tempo, a ser aplicada tanto nas províncias quanto na metrópole (TUCCI; AZEVEDO, 2001a, p. 140-141).

${ }^{63}$ Como consequência da centralização dos poderes nas mãos do príncipe, a função criadora do direito confiada aos praetores e aos seus edicta foi progressivamente restringida com a fusão do ius praetorium e do ius civile, e com a sobreposição a esses de um direito, por assim dizer, estatutário, de direta emanação imperial (CAPPELLETTI, 2005, p. 419). 
pela lex Julia iudiciorum privatorum, em 17 a.C. Contudo, sopesado o contexto da época, representavam grandes avanços.

O processo formulário sobreveio como uma alternativa mais moderna em relação às ações da lei, por ser menos formalista e mais ágil e funcional. Originou-se provavelmente nos territórios conquistados por Roma durante o século III a.C., quando os estrangeiros conquistaram o direito de ser parte. Como as legis actiones eram admitidas apenas para os cidadãos romanos, os pretores peregrinos passaram a prever, mediante fórmulas, as hipóteses em que os estrangeiros poderiam propor a ação (ou romanos em face de estrangeiros). Além de ser mais célere este processo per formulas, os pretores passaram a discricionariamente a admitir ações em hipóteses que não-previstas no direito quiritário, i. é, em situações em que os próprios cidadãos romanos não podiam demandar em razão das limitações das ações da lei. Assim, pouco a pouco, o processo formulário foi tomando o espaço das ações da lei, mesmo nas causas entre quirites, até ser instituído como o rito ordinário para fazer valer todas as classes de pretensões por Otaviano Augusto, por meio da citada Lei Julia.

O período clássico representou o apogeu do Direito Romano, sobretudo do ponto de vista do direito material. Este clímax se deve ao papel desempenhado pelo pretor no processo formulário. Embora permanecesse atribuição do iudex o julgamento da causa, ampliaram-se significativamente os poderes do pretor. Não tanto na condução do processo, em que seguia sendo mormente a redação da fórmula junto com as partes e, assim, determinar os limites objetivos da controvérsia. O mais importante nesse interregno foi a de assumir o poder de criar direito. Por meio de seus editos anuais, os pretores começaram discricionariamente a prever direitos que não estavam previstos no direito quiritário ou a modificar os já existentes. E quiçá por influência da filosofia grega, sobretudo pela ética aristotélica, os pretores passaram a considerar o justo ideal ao criar essas novas normas jurídicas. Conquanto tenha se encerrado com a aprovação do Edictum Perpetuum Salvvi Juliani, essa atividade criativa dos pretores inspirada na aequitas impulsionou significativamente o Direito Romano à época, erigindo-o a outra categoria e construindo uma autêntica Ciência do Direito.

A derrocada do sistema processual formular iniciou, ainda que timidamente, pela mesma lei que o oficializou, promulgada poucos anos após o início do principado, quando os poderes se concentraram nas mãos do príncipe. Assim como oficializou o processo formulário, a lex Julia iudiciorum privatorum estabeleceu a cognitio extraordinaria do princeps ou de seus delegados. Cônscio de que o processo constitui instrumento de poder, o gênio político Otaviano Augusto impôs que determinadas causas tramitariam, do início ao fim, perante uma única autoridade estatal, ele próprio ou um delegado seu. Estava lançada a gênese de um novo sistema processual que foi paulatinamente substituindo o processo formulário até o governo de Diocleciano (285-305 d.C.), quando se extinguiu de 
vez o ordo iudiciorum privatorum. Era chegada a hora dum novo sistema, denominado pela historiografia moderna de cognitio extra ordinem, que perduraria até os últimos dias do Império Romano no Ocidente.

Como consequência da centralização dos poderes nas mãos do príncipe, a função criadora do direito confiada aos praetores e aos seus edicta foi progressivamente restringida com a fusão do ius praetorium e do ius civile, e com a sobreposição a esses de um direito estatutário, de direta emanação imperial (CAPPELLETTI, 2005, p. 419). Durante o Dominato, o ordenamento jurídico romano se consolidou em um regime no qual prevalecia a lei, expressa nas Constituições Imperiais, como a uma única fonte do direito a lei. Mesmo quando é compilado o Direito Romano por ordem de Justiniano, as antigas fontes do período clássico romano passam a ser dotadas de caráter geral, coroando-se a supremacia da lei e adotando-se ao imperador como o único legisladorintérprete do direito. A diferente concepção no período pós-clássico da relação entre lei e a interpretação, submetendo esta àquela, foi uma das causas da decadência da ciência jurídica em Roma e de sua redução ao trabalho sem brilho e modesto das escolas de direito da época (CARMIGNANI, 2009, p. 126-127).

Mesmo após a queda do Império Romano no Ocidente, a Europa Ocidental permaneceu sob sua subjugação por vários séculos. Esse fato decorreu não apenas em razão do extenso tempo de imperialismo romano, mas pela sofisticação política, administrativa e jurídica atingida por aquela civilização romana. E com o renascimento no século XIII, ocorrido principalmente pelo seu estudo nas universidades a partir do século XII, o Direito Romano influenciou quase todos os sistemas jurídicos europeus na Idade Média. A codificação justinianéia, contendo as riquíssimas fontes do período formulário, amparou toda a evolução posterior dos direitos europeus, persistindo, até os dias de hoje, as marcas do processo formulário nos códigos modernos, mormente nos países que integram a família romano-germânica, como é o caso do Brasil. Com a sua integração ao direito comum da Idade Média, fonte substancial do Direito português durante o período colonial, o Direito Romano permeou no Direto brasileiro como herança lusitana, permanecendo até hoje esse legado.

Porto Alegre, junho de 2012.

Referências

ACCARIAS, Calixte. Précis de droit romain. Paris: Pichon, 1886-1891. 2 v.

ALVES, José Carlos Moreira. As bases romanísticas do direito brasileiro. In: TAVARES, Ana Lúcia de Lyra (Org.). Direito público romano e política. Rio de Janeiro: Renovar, 2005. p. 9-21.

. Direito romano. Rio de Janeiro: Forense, 1978. v. 1. 
. Universidade, cultura e direito romano. Revista Trimestral de Jurisprudência dos Estados, São Paulo: Jurid Vellenich, v. 121, p. 9-28, 1994.

ARANGIO-RUIZ, Vincenzo. Las Acciones en el derecho privado romano. Traducción de Faustino Gutiérrez-Alviz. Madrid: Revista de Derecho Privado, 1945.

. Istituzioni di diritto romano. Napoli: Jovene, 1952.

. Storia del diritto romano. Napoli: Jovene, 1968.

ARISTÓTELES. Ética a Nicómaco. Trad. José Luis Calvo Martínez. Madrid: Alianza, 2001.

AZEVEDO, Luiz Carlos de. O direito de ser citado: perfil histórico. São Paulo: Resenha Universitária, 1980.

. História do direito, ciência e disciplina. Revista da Faculdade de Direito, Universidade de São Paulo. São Paulo, 1997. v. 92, p. 31-49.

. Introdução à história do direito. São Paulo: Revista dos Tribunais, 2005.

BÖTTCHER, Carlos Alexandre. Iurisdictio praetoria: história do pretor das origens aos edito perpétuo. 2008. 188p. Dissertação (Mestrado) - Faculdade de Direito, Universidade de São Paulo, São Paulo.

CRUZ, Guilherme Braga da. O direito subsidiário na história do direito português. Coimbra: Universidade de Coimbra, 1975.

CAPPELLETTI, Mauro. O processo civil italiano no quadro da contraposição "civil law”-“common law": apontamentos histórico-comparativos. Traduzido por Daniel Ustárroz e Handel Martins Dias. Revista da Ajuris, Porto Alegre, n. 100 (edição histórica), p. 409-42, 2005.

. Processo e ideologie. Bologna: Il Molino, 1969.

CARMIGNANI, Maria Cristina da Silva. A aequitas e a aplicação do direito em Roma. Revista da Faculdade de Direito. Universidade de São Paulo, São Paulo, v. 104, p. 115-129, 2009.

. O direito judiciário na história: a experiência romana e luso-brasileira: utilização como forma de resolução dos anseios sociais por justiça. 2004. 110p. Tese (Doutorado) - Faculdade de Direito, Universidade de São Paulo, São Paulo.

CINTRA, Geraldo de Ulhoa. De actione sacramento. São Paulo: [s.n.], 1960.

; CRETELA JÚNIOR, José. Dicionário latino-português. São Paulo: Anchieta, 1947.

_. De statu civitatis: alguns aspectos da cidadania romana. São Paulo: Revista dos Tribunais, 1963.

COSTA, Emilio. Corso di storia del diritto romano: dalle origini alle compilazioni giustinianee. Bologna: Ditta Nicola Zanichelli, 1901.

. Il diritto nei poeti di Roma. Bologna: Ditta Nicola Zanichelli, 1898. 
COSTA, Emilio. Profilo storico del processo civile romano. Roma: Athenaeum, 1918. . Storia del diritto romano pubblico. Firenze: Barbéra, 1920. (Manuali Barbéra, v. VII).

COSTA, Moacyr Lobo da. Gaio: estudo biobibliográfico. São Paulo: Saraiva, 1989. . A revogação da sentença: gênese e genealogia. São Paulo: Ícone, 1995.

DIAS, Handel Martins. A evolução dos poderes do pretor na história do processo civil romano. Intertemas: Revista da Toledo, Presidente Prudente, v. 15, p. 205-225, 2010.

A influência do processo canônico no processo civil brasileiro. Intertemas: Revista da Toledo. Presidente Prudente, v. 16, 2011(no prelo).

ENGELMANN, Arthur. A history of continental civil procedure. Boston: Little Brown, 1927. (The continental legal history series, v. VII).

FERRI, Enrico. Pretor. In: Enciclopedia del Diritto. Milano: Giuffrè, 1986. v. 35.

GAIUS. Institutas do jurisconsulto Gaio. Tradução e J. Cretella Jr. e Agnes Cretella. São Paulo: Revista dos Tribunais, 2004.

GÉLIO, Aulo. Noites áticas. Trad. José Rodrigues Seabra Filho. Londrina: Eduel, 2010.

GILISSEN, John. Introdução histórica ao direito. Tradução de A. M. Hespanha e L. M. Macaísta Malheiros. Lisboa: Calouste Gulbenkian, 2003.

GRIMAL, Pierre. Histoire de Rome. Paris: Fayard, 2003.

JELLINEK, Geog. Teoría general del estado. Traducción de la segunda edición alemana y prólogo por Fernando de Los Ríos. Buenos Aires: Albatros, 1954.

KASER, Max. Derecho romano privado. Versión directa de la 5. ed. alemana por Jose Santa Cruz Teijeiro. Madrid: Reus, 1968.

LACERDA, Galeno. Processo e cultura. Revista de Direito Processual Civil, São Paulo, v. 3, p. 74-86, 1961.

LIEBMAN, Enrico Tullio. Istituti del diritto comune nel proceso civile brasiliano. In: Studio in onore di Enrico Redenti nel xl anno del suo insegnamento. Milano: Giuffrè, 1951. v. 1, p. 579-607.

MADEIRA, Hélcio Maciel França. História da advocacia: origens da profissão de advogado no direito romano. São Paulo: Revista dos Tribunais: 2002.

MARCHI, Eduardo Cesar Silveira Vita. Aspectos de direito público romano: as constituições políticas da realeza e da república. Revista da Faculdade de Direito, Universidade de São Paulo, São Paulo, n. 100, p. 3-19.

MARKY, Thomas. Curso elementar de direito romano. São Paulo: Saraiva, 1995. 
MARQUES, Mário Reis. História do direito português medieval e moderno. Coimbra: Almedina, 2002.

MAZZACANE, Aldo. Infamia: diritto romano e intermedio. In: Enciclopedia del Diritto. Milano: Giuffrè, v. 21, p. 382-387, 1971.

MEIRA, Sílvio A. B. História e fontes do direito romano. São Paulo: Saraiva, 1966. . Instituições de direito romano. São Paulo: Max Limonad, 1971. 2 v. . A lei das XII tábuas: fonte do direito público e privado. Belém: [s.n.], 1956.

MIRANDA, Jorge. Manual de direito constitucional. Coimbra: Coimbra, 2003. t. 1: O Estado e os sistemas constitucionais.

MOMMSEN, Theodor. Compendio del derecho publico romano. Buenos Aires: Impulso, 1942. . História de Roma: excertos. Trad. de Antônio Pinto. Rio de Janeiro: Opera Mundi, 1971. MUÑOZ-ARRACO, José Manuel Pérez-Prendes. Interpretación histórica del derecho. Madrid: Universidad Complutense, 1996.

OLIVEIRA, Carlos Alberto Alvaro de. Do formalismo no processo civil. São Paulo: Saraiva, 1997. PEIXOTO, José Carlos de Matos. Curso de direito romano. Rio de Janeiro: Peixoto, 1943. t. 1: Partes introdutória e geral.

PILATI, José Isaac. Função social e tutelas coletivas: contribuição do direito romano a um novo paradigma. Jurisprudência Catarinense, Florianópolis, Tribunal de Justiça, v. 106, p. 177-95, $2004 / 2005$.

PORTUGAL. Ordenações afonsinas. Lisboa: Fundação Calouste Gulbenkian, 1998-1999 (facsímile da edição feita na Real Imprensa da Universidade de Coimbra, no ano de 1792).

PUGLIESE, Giovanni. Il processo civile romano. Roma: Ricerche, 1961-2. v. 1: Le legis actiones. . Milano: Giuffrè, 1963. v. II: Il processo formulare.

- Regole e direttive sull'onere della prova nel processo romano per formulas. In: Scritti giuridici in memoria di Piero Calamandrei, Padova: CEDAM, 1958. v. 3, p. 577-617.

SARAIVA, F. R. dos Santos. Novíssimo dicionário latino-português. Rio de Janeiro: Garnier, 1927. SILVA, Ovídio Araújo Baptista da. Jurisdição e execução na tradição romano-canônica. São Paulo: Revista dos Tribunais, 1996.

SUETÓNIO. Os doze césares. Trad. e notas de João Gaspar Simões. Lisboa: Biblioteca Editores Independentes, 2007. 
SURGIK, Aloísio. Anotações histórico-críticas em torno do binômio direito público-direito privado. In: Estudos em homenagem ao professor Washington de Barros Monteiro. São Paulo: Saraiva, 1982. p. 23-42.

. Da iniciativa das provas e dos poderes do juiz no direito romano e na atualidade. Genesis: Revista de Direito Processual Civil, Curitiba, n. 2, p. 454-65, 1996.

. Lineamentos do processo civil romano. Curitiba: Livro é Cultura, 1990.

. Litiscontestatio. Genesis: Revista de Direito Processual Civil, Curitiba, n. 19, p. 153-57. 2001.

TUCCI, José Rogério Cruz. A causa petendi no processo civil. São Paulo: Revista dos Tribunais, 1993.

. Jurisdição e poder: contribuição para a história dos recursos cíveis. São Paulo, 1987.

; AZEVEDO, Luiz Carlos de. Lições de história do processo civil romano. São Paulo: Revista dos Tribunais, 2001a.

Lições de processo civil canônico: história e direito vigente. São Paulo: Revista dos Tribunais, $2001 b$.

WATANABE, Kazuo. Da cognição no processo civil. São Paulo: Revista dos Tribunais, 1987. 